УдК 378

DOI: https://doi.org/10.17721/2415-3699.2020.11.09

N. Postoiuk, PhD (Pedagogical Sciences)

Taras Shevchenko National University of Kyiv, Kyiv

\title{
SPEECH OF A UNIVERSITY TEACHER AS AN IMPORTANT COMPONENT OF PEDAGOGICAL SKILLS
}

The article highlights the features of the speech of a university teacher as one of the most important components of pedagogical skills. The speech is considered as a tool of professional activity of a teacher, with the help of which it is possible to solve various pedagogical tasks, make a complex topic interesting, and the process of its study attractive, create a sincere atmosphere of communication, establish contact with students, reach mutual understanding with them. The teacher's speech should be adapted to solve specific problems that arise in pedagogical activities and communication. The main ways to achievement high quality of professional and pedagogical speech of the teacher and professional features of speech activity of the teacher have been analyzed. The functions of the teacher's speech (communicative, psychological, cognitive, organizational) have been highlighted.

It is established that professional communication with the audience should lead to concrete positive results, which can be achieved through the use of knowledge of speech techniques, so the components of speech techniques such as breathing, voice, diction, intonation, tempo have been analyzed.

Keywords: teacher, university, speech, pedagogical skills.

Formulation of the problem. In the modern world, much attention is paid to the training of teachers universities, because the formation of real specialists, their professional qualities and skills, responsibility and attitude to work that will determine the vectors of state development depends on teachers. The university teacher should be a role model for the younger generation, as he or she will be followed and perceived as a standard. Every teacher must have pedagogical skills, one of the components of which is mastering the technique of speech. Undoubtedly, one of the most effective means of learning is the word of the teacher, thanks to which he or she can convey information, influence the audience, persuade, explain, and so on. The speech is the main tool with which the teachers can achieve the goal and implement the tasks they have identified for a particular class. Mastering the art of speech allows to inspire a person, inspire a good deed, interest in an idea, encourage productive activities and help in any difficult situation. The teacher must be able to regulate the strength and pitch of the voice, intonation, diversify the tone of speech, clearly articulate sounds and more. A teacher who is engaged in self-improvement of his or her speech achieves significant professional success. Speech skills as a means of professional activity must be learned. A classic example of this is the experience of A. Makarenko. The young teacher, feeling his helplessness in communicating with students, began to work hard, improving his voice, diction, breathing. His conclusions are known: "I became a real master only when I learned to say "Come here" with 15 - 20 shades, when I learned to give 20 nuances on the face, in the figure and in the voice and then I was not afraid that someone would not come to me or hear what was needed". [3, p. 58].

Analysis of recent research and publications. Many studies have been devoted to the study of speech technique. T. Vakhrusheva, V. Kan-Kalyk, L. Kaidalova, N. Shchokina, V. Fedorchuk, N. Pykhtina, V. Semichenko, I. Zyazyun and others dealt with the problems of theoretical principles of speech technique. The views of L. Vygotsky, I. Zymna, O. Kyrychuk, A. Kapska, L. Necheporenko, and V. Tesliuk point to objective need and possibility of formation of this important component of pedagogical skill.

Research goal and objectives. The goal of the article is to analyze the features of the teacher's speech technique in the context of the activities in higher education. The objectives are: 1) to consider the peculiarities of the university teacher's speech and its functions; 2) to analyze the structural components of speech technique and practical exercises for the formation of pedagogical speech; 3 ) to determine the conditions of proper phonation breathing and the basic hygienic requirements for the teacher's voice.
Study presentation. It is well known that the teacher's speech is one of the components of pedagogical skills, which can be considered as the highest level of pedagogical activity and as a set of personality traits that provides selforganization of a high level of professional activity on a reflective basis [3, p. 30]. The teacher's speech is adapted to solve specific problems that arise in pedagogical activities and communication. We can talk about the professional features of the speech activity of the teacher, namely:

a) the teacher specially organizes this activity, manages it depending on the conditions of pedagogical communication;

b) the final result of such activities is a humanistic achievement the directed purpose connected with education of students;

c) the selection of language and speech means is carried out depending on needs, tasks of interaction of the teacher with students; their effectiveness is predicted;

d) speech activity of the teacher in a real communication situation is based on the reproduction (reflection) of the state, behavior, reaction of students, it is regulated by the content of feedback received by the teacher;

e) the teacher's speech is the subject of his or her pedagogical analysis and self-analysis, constant selfimprovement.

The teacher's speech is realized in two varieties - in monologue (monologue speech) and in dialogue (dialogic speech). Forms of this speech are diverse. The most common are a story, a lecture, a commentary, explanation (rules, laws, terms, etc.), detailed evaluation judgments (motivation for assessing knowledge, behavior, extracurricular activities of students). The teacher's dialogic speech is widely represented in various conversations with students, which are built in the form of questions and answers.

Analyzing the teacher's speech, it is often used the phrase "communicative behavior" that is understood not just as the process of speaking, communicating, but such organization of speech and nonverbal behavior of the teacher, which affects the emotional and psychological atmosphere of pedagogical communication, the nature of the relationship between a teacher and students, their style.

The communicative behavior of the teacher is assessed according to what and how he or she speaks, what gestures, movements, facial expressions, what subtext the words have, what reaction students are designed for. In real situations of the university life the speech side of communication is a complex polyphony of remarks, stories, questions, evaluative judgments, answers, remarks, 
emotional reactions. This specific atmosphere is the result of communicative behavior of teachers and students. Every time it is unique and in this sense - instantaneous. Students after the meeting with the teacher not only get the cognitive information the teacher has provided, but also the atmosphere that accompanied their communication. Students have the mood of the impression of meeting with the teacher, the memory of his or her gaze, intonation, tone of speech, way to respond to behavior of the students. That is why it is so important when planning a meeting with students, to consider not only the content of communication, but also features of the speech and communicative behavior because verbal and nonverbal means will give me the chance to be expressive, convincing and as a result specific emotional atmosphere of communication will be created.

The pedagogical effectiveness of the teacher's speech largely depends on the level of language proficiency, the ability to make the right choice of language means. The pedagogical effectiveness of the teacher's communicative behavior depends primarily on what style of communication with students is chosen by the teacher, what intentions the pedagogues have and how they feel the psychological features of the speech situation. It is possible to see the difference in communicative behavior between an autocratic teacher and a humanist teacher, a teacher who is indifferent to students and who is focused on cooperation with them.

The teachers whose communication style with students is based on a friendly attitude to them, have communicative behavior that is always aimed at establishing personal and cognitive contact, preventing or removing negative reactions, creating a situation of "we" - a situation of shared reflection and feelings. The speech of such a teacher is intonationally expressive, sincere and direct.

Communicative behavior of teachers focused on authoritarian means of communication, for the most part, creates psychological and aesthetic barriers in students' relationships with teachers. The speech of such teachers is usually indistinct, dry, marked by intonations of indifference or intimidation. Thus, the level of skill of the teacher's speech activity is determined by the level of culture of his speech and the direction of his communicative behavior [3, p. 59-60].

Requirements for the communicative qualities of the teacher's speech are due primarily to the functions it performs in teaching. The main requirements are: 1) communicative establishing and regulating relations between a teacher and students, ensuring the humanistic orientation of student development; 2) psychological - creating conditions to ensure the psychological freedom of the student, the manifestation of individual identity, removing social clamps that prevent it; 3 ) cognitive - ensuring the full perception of educational information by students, the formation of their personal, emotional and value attitude to knowledge; 4) organizational ensuring the rational organization of educational and practical activities of students.

So establishing and regulating the relationship between a teacher and students, ensuring the humanistic orientation of students' development is one of the leading functions of teacher's speech, and the goal is to help teachers establish interaction with their students, build education and training on the basis of cooperation and collaboration. It is the nature of purely human relations, which are formed in the system of relations "a teacher - a student", "a teacher - students", largely determines the pedagogical success or failure of teacher speech and acts as a regulator of these relations, acts as a means of achieving the highest result in communication.
In general, in the teacher's relationship with students everything matters: how the teachers address them, how they make their demands, make remarks, express wishes, what is the emotional color of the speech, what intonation they accompany their words, which facial expression and look they have.

Peculiarities of a teacher's speech in interaction with students largely depend on his individual style of communication (it can be communication-distance, communication-flirting, communication on the basis of common creative activity, etc.), the nature of social attitudes in pedagogical communication with students. Of course, if the teacher is characterized by an authoritarian style of communication and negative social attitudes, then he or she can not be expected to make correct remarks, friendly intonations. Democracy in relationships will lead to a different style of speech, which will demonstrate the respect and trust of the teacher to students [3, p. 61].

According to $\mathrm{V}$. Teslyuk, the technique of speech means the ability to possess a voice, intone a speech and control the audience [4, p. 121]. V. Fedorchuk defines the technique of speech as a set of elementary techniques of phonation breathing, speech voice and diction, brought to the degree of automated skills, which allows the teacher to exercise speech influence with maximum efficiency. These are skills, the ability to implement language in a specific speech situation so that it makes a listener heuristic (intellectual), emotional-aesthetic, motivating impression [5, p. 52].

Based on the analyzed literature sources, we can determine that the technique of speech has the following components: breathing, voice, diction, intonation, tempo. Knowing the peculiarities of functioning and the basic requirements for the formation of these components, the teacher will be able to master the professional and pedagogical speech. It will be useful to consider in more detail each of the elements of speech technique. Breathing is defined as one of the main vital acts of the human body, which a person performs constantly, in a certain rhythm. At the same time, breathing is the basis of spoken speech. Speech breathing is called phonation (from the Greek "phono" as a sound). In the process of breathing nasopharynx, bronchi, lungs, chest, diaphragm are actively involved. For their work to be correct and effective, they must be physically healthy and developed. The quality of breathing also depends on the age of the speaker. Depending on which muscles are involved in the process of breathing, there are 4 types: 1) Upper or clavicular breathing is carried out by contracting the muscles that raise and lower the shoulders and upper chest. This is shallow breathing, during which only the upper part of the lungs works. 2) Chest breathing is performed by the intercostal muscles. The diaphragm is sedentary, so the exhalation is not energetic enough. 3) Diaphragmatic breathing occurs due to contraction of the diaphragm muscles (contraction of the intercostal respiratory muscles is very small).

Usually, a person uses all three types of breathing, but each is dominated by a certain type. Thus, female respiration in the process of evolution has developed as predominantly thoracic, and males breathe mostly through the diaphragm. The most effective - the most complete and correct - is the fourth, mixed, type of breathing:

4) Rib-diaphragm, ie, when in the process of breathing the ribs and diaphragm move. You can see this if you put your right hand on the diaphragm, and the left - on the left side of the chest; taking air through the nose, slightly holding it, say the phrase (exhaling air during its utterance, you must 
feel the movement of the ribs and diaphragm). In this case, there is a complete expansion of the thoracic cavity, maximum ventilation of all parts of the lungs. Tension of the lower intercostal muscles allows you to keep the diaphragm in a reduced state, which contributes to a calm, even exhalation, invisible to others.

Breathing has two main acts: inhalation and exhalation, the quality of which also accordingly colors the sound speech, and the pause between them is an indicator of the nature of respiration. Thus, the sequence of normal physiological breathing is inhale, exhale, pause, where inhale and exhale are short and the same duration. In everyday life, when a person's speech is mostly dialogical, breathing does not cause difficulties. But for monologue speech physiological (or unintentional) breathing is usually not enough. Speaking and reading aloud require a lot of air, its economical consumption and timely renewal. In class, especially when the teacher has to talk for a long time, explaining the material, reading a lecture, untrained breathing can cause problems and the heart rate may increase, the face may turn red, shortness of breath can appear.

However, breathing can also be controlled: intentional (phonation) breathing, in contrast to physiological, is carried out in a different sequence: short breath, pause, long sound exhalations. If in normal physiological respiration the ratio of inhalation and exhalation was 1: 1, then in phonation it changes in the ratio $1: 10,1: 15$. At the initial stage of mastering speech breathing is carried out with the help of will and consciousness. Subsequently, intentional (arbitrary) speech breathing turns into unintentional (involuntary) [5, p. 53-54].

An important feature of the regulation of respiration in humans is the ability to arbitrarily, depending on the purpose, including speech, to change the pace, rhythm, activity, amplitude of respiratory movements. In the process of developing phonation breathing skills should be guided by the following conditions of proper breathing:

1. Inhale air through the nose should be free, silent.

2. You can start speaking when the lungs take a small excess of air needed to pronounce the structural and logical part of the text: it will relieve the "extraordinary" breath, which disrupts the smoothness and rhythm of speech, causes intermittent, shallow breathing.

3. Do not allow the air to be expended completely (ie do not allow complete release of the lungs from the air) - this will lead to arrhythmia, falsetto, etc. Air should be used sparingly and evenly. You should use every natural stop in your speech to get air in your lungs. (Extraction of air during natural stops is carried out by the so-called lower breath; the diaphragm moves, and the top part of a thorax and ribs are lifted and motionless).

It is necessary to replenish a stock in due time and imperceptibly.

4. Remember that the depth of inspiration depends on the strength of the exhalation, hence the strength of the voice.

5. Inhale and exhale should be silently, unnoticed for the listener, because high-quality sound is formed by a calm stream of air that comes out during equal inhalation and exhalation (this is not about affective speech) [1, p. 165].

There are exercises that help improve the teacher's respiratory system. For example, the exercise "Fixed exhalation", when after a slight calm inhalation it is necessary to make exhalations, covering the air coming out of the lungs with the lips. You do not need to inflate the cheeks. The lips should be close together, and there should be a small gap in the middle between them, which can be made larger or smaller, thus regulating the flow of exhaled air. You need to raise your hand to your mouth, as if gently blowing it, and try to blow on your hand as long as possible, while maintaining the same pressure of exhaled air until the end of exhalation. Exhale smoothly and freely until you have an involuntary urge to inhale. It is necessary to follow the correct posture and absolute freedom of the shoulder girdle, neck, arms, face. At the moment of a second stop, mentally instruct the muscles responsible for exhalation to relax. A small amount of air will enter the lungs through the nose quickly and freely, without much effort - it is quite enough to be able to "blow on the arm" again. The following exercises can be as follows: 1) perform a "fixed exhalation" while counting "about yourself", trying to distribute the duration of exhalation for $10,12,15$ or more seconds; 2 ) dividing the duration of exhalation by 15 seconds, count to 10 or 12 mentally, and then complete the count aloud. Instead of counting, you can say loud sounds: a, o, y, e, y, and or proverbs, a verse; 3 ) take a deep short breath, and on the exhale say the sounds: bbb, ddd, yyyy, bdg, dbg, gdb, ss, $\mathrm{sz}, \mathrm{pt}, \mathrm{pb}, \mathrm{dt}, \mathrm{bp}, \mathrm{td}, \mathrm{kg}, \mathrm{gk}, \mathrm{mn}, \mathrm{nm}$, zhsh, shzh, j, dz. When pronouncing sounds, one should imagine their origin: the operation of a jackhammer, a concrete mixer, motor noise, and so on. [5, p. 132-133].

The most important element of speech technique, which for the teacher is the main means of work is the voice. Inhaling and exhaling air in the process of speaking, a person makes the vocal cords close and open. As a result, a voice appears. It is stimulated by the speaker's intellect, his or her emotions (desire to speak), will. The voice itself is weak. In order for it to sound, it is necessary to amplify the sounds of the voice. It is carried out by resonators (amplifiers): chest, palate, teeth, nasal cavity, facial bones, frontal sinuses. There are upper resonator (mouth, nose) and lower, thoracic resonator (respiratory throat, bronchi, lungs). Thus, the sound of the voice, its main properties largely depend on the construction of resonators, on the state in which they are and whether the sound of the voice is properly directed to the resonators [5, p. 54].

Consider the main properties of the teacher's voice: strength, flight, flexibility, range, timbre, melodiousness.

The strength (volume, sonority) of the voice does not depend on physical effort, which leads to tension in the muscles of the larynx and vocal cords, but on proper, active speech breathing, the activity of the speech apparatus, the ability to use resonators. Strength is more completeness, compactness, than the volume of sound, and is determined by the space that the sound must fill. K.S. Stanislavsky emphasized that when you need the real power of speech, you need to forget about the volume. The teacher should choose a medium volume and never resort to increased volume (screaming), because the scream strains the vocal cords and very quickly ceases to attract the attention of listeners.

Flight of the voice is the ability to "send" your voice to a distance and adjust the strength of the voice; the ability of the voice to stand out against other sounds. Together with the power, it provides normal audibility at various points in the audience. A prerequisite for the flight of the voice is the psychological attitude of the teacher to communication. The flight of the voice also depends on how correctly the teacher assessed the peculiarities of the acoustics of this audience, is able to "give" the sound, to provide a link. The clarity of articulation also plays an important role in ensuring flight, as the indistinct work of the speech organs does not allow the formation of a full-fledged sound.

Voice flexibility (mobility) is associated with the ability to choose the following characteristics that correspond to 
specific communication conditions: it is a change of voice within the existing range, and adaptability (ie adaptability of the voice to acoustic conditions in which the teacher is forced to speak), and the ability to overcome voice sound interference (conversations, extraneous noises). The flexibility of speech lies in the lightness, variety of increases or decreases from the main tone, in changes of timbre in accordance with the requirements - logical and artistic - of a particular text. For the most part, the flexibility of the voice is related to its changes in pitch. The human voice can vary freely in pitch by about two octaves, although in everyday speech we use three to five tones.

Range is the volume of a voice. Its boundaries are determined by the highest and lowest tones. Narrowing the range of the voice leads to monotony, impoverishment of the sound palette. The monotony of sound, in turn, dulls perception, weakens the pedagogical influence of speech.

Timbre is the color of a sound, its brightness, softness, warmth, individuality, that is, what distinguishes the voice of one person from another.

The melodiousness is the purity and freshness of the timbre (without extraneous sounds: wheezing, stiffness, etc.), the innate beauty of the voice, which does not cause negative feelings for the listeners. Melodiousness, and especially its components such as purity and clarity of timbre, are largely determined by natural data. However, there is an opportunity to improve such "components" of melodiousness as tempo and height.

Suggestiveness is the ability of the voice to influence the listener, to broadcast, to inspire with the necessary emotional state, even regardless of the content of speech. Suggestiveness largely depends on the timbre, and is trained in the process of improving the expressive side of speech, especially intonation flexibility and range.

Endurance is the ability to have a certain load. Voice endurance is ensured by correct speech breathing, clear articulation, quality of reasoning and compliance with a number of requirements, the most important of which are the hygiene of the vocal cords. After a working day it is necessary to refrain from conversations for several hours or try to communicate in very short phrases with minimal sonority [5, p. 55-56].

Studies show that the incidence of vocal apparatus in teachers is $40.2 \%$ [5, p. 56]. The main causes of voice disorders: increased daily load, incompetent use of the vocal apparatus, non-compliance with the rules of hygiene, congenital weakness of the vocal apparatus. Therefore, before long-term speech, it is necessary to choose from the beginning such a strength and volume that would not lead to overstrain of the vocal cords. Every teacher should keep in mind the basic hygiene requirements for the voice:

1. Remember that vocal cords are worn out, depleted, and should not be strained or forced to work without rest beyond the critical time limit for the voice.

2. When drawing up the schedule of training sessions it is necessary to consider that fatigue of the vocal apparatus arises as a result of teaching within 3-4 hours of work and disappears in 1 hour complete voice rest (this applies to teachers with up to 10 years of experience). A teacher with more experience gets tired faster in 2-3 hours and rests longer up to 2 hours.

3. At the end of the working day, the teacher should avoid long conversations for 2-3 hours. If necessary, speech should be quiet with short phrases (concise).

4. Since the beauty and strength of the voice depend on the respiratory organs, larynx and resonator cavities, care should be taken for their coordinated work, which is possible primarily under the condition of their good physical condition (health).

5. You should pay attention to the state of health of the upper respiratory tract, nervous system, diet. The vocal apparatus is very sensitive to spicy food. Too hot, cold, spicy foods, alcoholic beverages, smoking cause redness of the mucous membranes of the mouth and pharynx.

6. Monotonous speech tires the muscles of the vocal apparatus, because in such speech only one group of muscles functions.

7. Every change of voice properties, in particular changes of registers, tempo, volume should be carried out effortlessly, without stress (this ensures the efficiency of the voice organs) and unnoticed for listeners, which can achieve persuasiveness, organicity of our perception and perception of the listener.

8. Inhalation of chalk dust is harmful, so the cloth for the board should always be wet.

9. You can not walk fast on cold days after voice work, because with intense movements, breathing becomes more frequent, deeper and more cold air enters the airways.

10. Since the improvement of the tone depends on our will, it must subordinate our mood, psychological characteristics, physical condition and so on.

11. Remember that smoking and drinking alcohol or drugs have a negative effect on the voice [5, p. 134].

Here are some exercises that will help develop the properties of the voice. For example, you need to read verses with a gradual decrease in the voice register, and then read with a gradual increase in the voice register.

The next exercise on the flight of the voice can be as follows: stand in front of the audience and read a poem in a whisper, providing good audibility in all corners of the room, you need to try to "give" the sound, "send" it away, keeping not volume but strength, energy exhale.

Consider the next component of speech technique diction. Diction is a clear and distinct manner of pronouncing words, syllables and sounds [2, p. 89]. It is a professional necessity for the teacher, as it contributes to the correct perception of students of the teacher's speech. Careless pronunciation makes speech slurred and unintelligible. This is manifested in the "eating" of the final consonant or the sounds inside the word, the sound "through the teeth". In general, you need to speak fluently, learn to open your mouth well, which is an important condition for the formation of sound. Good diction prepares the speech apparatus for the creative process, makes the usual accurate articulation of all speech sounds, helps the expressiveness of speech. Wrong skills, speech defects that have become entrenched over the years will not be able to disappear quickly. Only consistent training, continuous work and endurance will help to get rid of the usual incorrect movements of some parts of the speech apparatus, replacing them with other, not yet usual, but correct movements, and make these movements relaxed [5, p. 56-57].

Here are some exercises that can train diction. To develop diction, tongue twisters are effective. Working on them has its own characteristics. First of all, you need to read the tongue twister carefully, slowly, finding out its meaning. The next stage is soundless articulation: the text is not pronounced aloud, but the work of the speech organs is carefully reproduced without the participation of the voice. During such silent articulation, the speech organs become accustomed to the correct work during the formation of a sound. Only then the tongue twister is spoken aloud, at first slowly, diligently articulating. Finally, the tongue twister should be spoken, following the clarity of the 
articulation, gradually increasing the pace. For effective rehearsal, it is necessary to pronounce a tongue twister clearly 3-5 times at a fast pace.

It should be noted about such a component of speech technique as the rate of speech, ie the speed of oral speech, which is measured by the number of sounds or syllables spoken per second [2, p. 327]. Some scholars distinguish such a concept as temporitum: it is the speed as a whole and the duration of the sound of individual words, syllables, as well as pauses in combination with the rhythmic organization, the dimension of speech. The speed of speech depends on the individual qualities of the teacher, the content of his speech and the situation of communication. The duration of the sound of individual words depends not only on their length, but also on their significance in this context. The teacher teaches a complex part of the material at a slow pace, then he can speak faster. Speech is necessarily slowed down when it is necessary to formulate one or another conclusion - definition, rule, principle, law [5, p. 57].

To achieve the expressiveness of the sound should be skillfully used pauses: logical and psychological. Without logical pauses, speech is illiterate, and without psychological pauses, it is dead. Pauses, tempo and melody of speech together make intonation. Intonation is a change in pitch, strength, timbre of the voice, the division of speech by pauses in the process of its deployment [1, p. 198]. Intonation expressiveness of speech can emphasize, strengthen the creative idea of the author or modify, distort it. The teacher's speech should attract with its naturalness, conversational melodic pattern and, unlike ordinary conversation, be more contrasting, more expressive. Emphasis, tempo and melody organize speech and are most clearly manifested in the intonation not of a single word, but of a group of words, ie in the speech flow, in oral speech. The tempo is not independent because it repeats the position of emphasis, ie it is determined by the dynamics of the word, phrase. The melody is created by contrasting stressed and unstressed syllables, stressed and unstressed words. Thus, temporitum, intonation expressiveness of speech is an extremely complex mechanism, which is activated by physiological, intellectual-logical and psychological levers. This mechanism will work flawlessly if the speaker has a trained hearing on the spoken word, if he is psychologically tuned to the perception of the word, will not remain indifferent to it and if he has a variety of accurate means necessary for semantic, logical and emotional expression [5, p. 57]. Exercise "Pedagogical intonations" is aimed at the development of temporitum: it is necessary to read with different intonation: fun, sad, businesslike, angry, harsh, friendly, thoughtful, surprised.

The teacher must constantly work to develop pedagogical speech and try to succeed in professional pedagogical activities.

Conclusions. Thus, the speech of a university teacher is one of the most important components of pedagogical skills. The functions of the teacher's speech (communicative, psychological, cognitive, organizational) show the requirements to the communicative qualities of the teacher. The main ways to achievement high quality of professional and pedagogical speech of the teacher and professional features of speech activity of the teacher have been analyzed, namely speech management depending on conditions of pedagogical communication, such final result of speech as achievement of the humanistically directed purpose, selection of language and speech means depending on needs of teachers and students; construction of speech activity of the teacher in a real situation of communication on the basis of reflection of a condition, behavior, reaction of students. The level of mastery of such elements of speech technique as breathing, voice, diction, intonation, tempo determine the quality and effectiveness of professional and pedagogical speech of the teacher. The process of communication of the teacher with the audience should lead to concrete positive results, which can be achieved through the use of knowledge of speech techniques. Undoubtedly, the success of a teacher's professional activity depends on the technique of speech, which includes the ability to breathe properly, intonate speech and pause, clear diction and timbre of speech. It is determined that in the process of developing phonation breathing skills should be guided by the following conditions of proper breathing: inhale air through the nose should be free, silent; you can start talking when a slight excess of air is taken into the lungs; to spend air it is necessary economically and evenly; you should use every natural stop in speech to get a supply of air in the lungs; the strength of the exhalation depends on the depth of inspiration, hence the strength of the sound of the voice; inhale and exhale should be silent, unnoticed for the listener, because high-quality sound is formed by a calm stream of air that comes out during inhalation and exhalation. After an objective assessment of your own speech data, you should start regular classes to correct the identified shortcomings, weaknesses of speech (to train breathing, practice diction, temporitum, strengthen vocal cords). It is well known that no one is born with professional and pedagogical speech, it is the result of long-term hard work and daily training. Systematic work on yourself and performing special exercises will help to improve speech technique. In the context of this issue, we can explore the the conditions for the effectiveness of professional speech and ways to improve it.

\section{References}

1. Babych N.D. Osnovy kultury movlennya. - Lviv: Svit, 1990. - 232 s.

2. Honcharenko S.U. Ukrayinskyy pedahohichnyy slovnyk. - K.: Lybid, 1997. $-375 \mathrm{~s}$

3. Pedahohichna maysternist : pidruchnyk /za red. I.A. Zyazyuna. Kyyiv : Vyshcha shkola, 2004. - $422 \mathrm{~s}$

4. Teslyuk V.M., Luzan P.H., Shovkun L.M. Osnovy pedahohichnoyi maysternosti. - K.: Natsionalnyy universytet bioresursiv i pryrodokorystuvannya, 2009. - $194 \mathrm{~s}$.

5. Fedorchuk V.V Osnovy pedahohichnoyi maysternosti. - KamyanetsPodilskyy: Vydavets Zvoleyko D., 2008. - $140 \mathrm{~s}$.

6. http://muza.dp.ua/?p=507\#more-507

Список використаних джерел

Бабич Н.Д. Основи культури мовлення. - Львів: Світ, 1990. - 232 с.

Гончаренко С.У. Український педагогічний словник. - К.: Либідь, 1997. $-375 \mathrm{c}$.

Педагогічна майстерність : підручник /за ред. І.А. Зязюна. Київ : Вища школа, 2004. - 422 с.

Теслюк В.М., Лузан П.Г., Шовкун Л.М. Основи педагогічної майстерності. - К.: Національний університет біоресурсів і природокористування, 2009. - 194 C.

Федорчук В.В Основи педагогічної майстерності. - Кам янець-Подільський: Видавець Зволейко Д., 2008. - 140 с.

http://muza.dp.ua/?p=507\#more-507

Надійшла до редколегії 08.11.19 
Н. Постоюк, канд. пед. наук

Київський національний унівнрситет імені Тараса Шевченка, Київ

\section{МОВЛЕННЯ ВИКЛАДАЧА УНІВЕРСИТЕТУ ЯК ВАЖЛИВИЙ КОМПОНЕНТ ПЕДАГОГІЧНОЇ МАЙСТЕРНОСТІ}

Висвітлено особливості мовлення викладача університету як одного з важливих компонентів педагогічної майстерності. Розглянуто мовлення як інструмент професійної діяльності педагога, за допомогою якого можна розв'язати різні педагогічні завдання, зробити складну тему цікавою, а процес ії вивчення - привабливим, створити щиру атмосферу спілкування, встановити контакт із студентами, досягти взаєморозуміння з ними. Мовлення вчителя має бути пристосоване для розв'язання специфічних завдань, що виникають у педагогічній діяльності, спілкуванні. Проаналізовано основні шляхи досягнення високої якості професійно-педагогічного мовлення викладача та професійні особливості мовленнєвої діяльності педагога, а саме керівництво мовленням залежно від умов педагогічного спілкування, такий кінцевий результат мовлення як досягнення гуманістично спрямованої мети, добір мовних і мовленнєвих засобів залежно від потреб, завдань взаємодії викладача та студентів; конструювання мовленнєвої діяльності педагога в реальній ситуації спілкування на основі рефлексії стану, поведінки, реакції студентів. Висвітлено функції мовлення викладача (комунікативна, психологічна, пізнавальна, організаційна).

Встановлено, що професійне спілкування з аудиторією має приводити до конкретних позитивних результатів, що може бути досягнуто завдяки використанню знань з техніки мовлення, тому проаналізовано такі складові техніки мовлення як дихання, голос, дикція, інтонація, темп.

Розглянуто мовлення викладача як предмет його педагогічного аналізу й самоаналізу, постійного самовдосконалення. Доведено, що успіх професійної діяльності викладача залежить від техніки мовлення, що включає вміння правильно дихати, інтонувати виступ та робити паузи, чітку дикцію та тембр мовлення. Після об'єктивної оцінки власних мовленнєвих даних варто розпочати регулярні заняття для виправлення виявлених недоліків, слабких сторін мовлення (тренувати дихання, відпрацьовувати дикцію, темпоритм, зміцнювати голосові зв'язки). Систематична робота над собою та виконання спеціальних вправ сприятимуть вдосконаленню техніки мовлення.

Ключові слова: викладач, університет, мовлення, педагогічна майстерність.

UDK 378.147.34

DOI: https://doi.org/10.17721/2415-3699.2020.11.10

Ye. Spitsyn, Doctor of Sciences (Pedagogics), Professor, Taras Shevchenko National University of Kyiv, Kyiv, Ukraine

\section{DEVELOPMENT OF THEORY AND PRACTICE OF LABORATOR LESSONS IN HIGHER SCHOOL BY A. D. BONDAR}

The article analyzes the contribution of the professor of the Department of Pedagogy of Taras Shevchenko National University of Kyiv A.D. Bondar in the development of theoretical principles and methods of conducting laboratory and practical classes in higher education, identifies the possibility of using this pedagogical experience in modern conditions.

It is established that today the work and pedagogical activity of A.D. Bondar is insufficiently studied, although his work reflects the results of research on important didactic problems that are relevant today. It is analyzed that among the various types of classes in higher education an important place belongs to laboratory and practical work, because they follow one of the leading principles of didactics - the principle of connection of theory with practice. According to A.D. Bondar, laboratory and practical works are closely connected with lectures and independent work of students, they, with their proper organization, help students to creatively use the theoretical knowledge that they acquired during lectures and in the process of studying literary sources. This type of training activates the cognitive activity of students, gives them the opportunity to show initiative and ingenuity, better master the program material, get acquainted with the latest installations and devices, equipment and materials, experiment in laboratory or production conditions, helps teachers to involve students in research work, promotes the development of their thinking, ingenuity, innovation. According to A.D. Bondar, laboratory classes are an effective way to study the material, give students the opportunity to apply their knowledge in practice and see the results of their work. At the same time, many factors significantly reduce the effectiveness of this important type of training. It is proved that the improvement of the quality of laboratory classes can help, in particular, the implementation of guidelines developed by A.D. Bondar almost half a century ago.

Keywords: laboratory, practical training, forms of organization of training, types of training, A.D. Bondar.

Formulation of the problem. As mentioned in our previous publications[7,8], in our opinion, the 60 s-80s of the last century were one of the most effective periods in the activity of the Department of Pedagogy of Taras Shevchenko University of Kyiv. The lead direction of activity of department at the specified time, was the pedagogisation of educational process. Doctor of pedagogical sciences, Professor Andrey Danilovich Bondar (1913-1983) took an active part in this work. As an associate professor A.D.Bondar worked at the department since 1963, as a professor - since 1970. One of the lead areas of its diverse research and educational activities was high school education, in particular, didactics of higher school. It was not by chance that he was instructed to lead the section of pedagogy of higher education at the department. In our previous academic explorations on the academic and pedagogical heritage of A.D. Bondar $[7,8]$ was analyzed his contribution to the development of theoretical and methodological bases of pedagogical practice of students, theory and methods of seminar classes conduction in high school.

The purpose of this article is determining the contribution of Prof. A.D. Bondar in developing theories and methods of most importantly (especially for science students) types of education classes in high school as a laboratory and a practical classes and topicality of his recommendations for modern higher education in Ukraine.

Presenting main material. The urgency of the study of this problem in the historical and pedagogical aspect is due to the need to significantly improve the effectiveness of training of future pedagogical staff in accordance with the requirements of the Concept of development of higher pedagogical education in Ukraine, in particular the content, forms of organization of methods and teaching aids. Wellknown Ukrainian academician in the field of didactics of high school A.D. Bondar devoted much of his life to the solution of these problems. Unfortunately, up to date, the works and educational activities of A.D. Bondar were insufficiently studied, although the of works A.D.Bondar show the results of the study of important didactic problem, which is topical today [4]. By education A.D. Bondar was a representative of the natural sciences, which is why he was extremely interested in the problem of improving the practical training of future specialists - he devoted a textbook on teaching practice (1972) to the analysis of these problems, and in 1977 at the publishing house "Higher School" (Teacher library) a book of A.D. Bondar (with L.A. Ranska as a co- 